\title{
Palmar Dermatoglyphics of Corsicans and Comparison with Those of Sardinians
}

\author{
G. Floris, C. M. Calò \\ Dipartimento di Scienze della Vita e dell'Ambiente, Università degli Studi di Cagliari, Monserrato, Cagliari \\ Email: giofloris@alice.it
}

How to cite this paper: Floris, G., \& Calò, C. M. (2018). Palmar Dermatoglyphics of Corsicans and Comparison with Those of Sardinians. Advances in Anthropology, 8, 316-322. https://doi.org/10.4236/aa.2018.84014

Received: June 5, 2018

Accepted: November 27, 2018

Published: November 30, 2018

Copyright () 2018 by authors and Scientific Research Publishing Inc. This work is licensed under the Creative Commons Attribution International License (CC BY 4.0).

http://creativecommons.org/licenses/by/4.0/

\begin{abstract}
We report on five dermatoglyphic traits recorded on palm prints in sample of Sardinians and Corsicans. The two populations are very similar but not identical.
\end{abstract}

\section{Keywords \\ Palmar Dermatoglyphics, Sardinians, Corsicans}

\section{Introduction}

Corsica and Sardinia probably have a similar history in terms of the first peopling of the islands (Francalacci et al., 2003). This is indicated by examination of $\mathrm{Y}$ chromosome haplotypes, with a small genetic difference between the present-day populations (Giovannoni et al., 2006; Varesi et al., 1996). Since digital and palmar dermatoglyphic patterns are non-adaptive traits free from environmental influences (Reddy and Reddy, 2006), they are also a good tool for population analyses (Jantz and Chopra, 1983; Adetona et al, 2008; Temaj et al., 2009; Mbaka et al., 2016). Previous fingerprint studies (Morelli et al., 1999 for males and females; Piquet-Thepot, 1963 only for males) did not show a clear difference between Corsicans and Sardinians, the former presenting a slightly higher percentage of loops (64.3\% vs $63.34 \%)$ in males and a lower one in females $(62.50 \%$ vs $66.45 \%)$ and a lower incidence of whorls in males $(28.5 \%$ vs $32.32 \%)$ and a higher one in females (30\% vs $25.23 \%$ ) (Floris, unpublished data). In this note, we report on a comparison of qualitative and quantitative aspects of palmar dermatoglyphic patterns between Corsicans and Sardinians.

\section{Technique and Method of Examination}

The palm prints of 107 Corsicans (54 males and 53 females) recorded by ink 
method were compared with the prints of Sardinians conserved in the Neurosciences and Anthropology Section, Department of Life Sciences and Environment, University of Cagliari (Floris, 1975a, 1975b; Floris, 1977; Floris, 1992). Corsican sample was constituted by healthy individuals of both sex, randomly selected, born and resident in the area of Corte (Central Corsica) for at least three generations. Sardinian data were constituted by 820 individuals of both sex born and resident for at least three generations in the city of Cagliari (Sardinia, Italy). The dermatoglyphic traits used for the comparison were: the presence of true patterns and vestiges in the five palmar areas; modal types of $\mathrm{C}$ line termination according to the Plato classification (Plato, 1970); a-b ridge count; A-d ridge count; main line index. Figure 1 showed the main lines and the triradii for the determination of the $\mathrm{a}-\mathrm{b}$ ridge and A-d ridge.

Statistical differences between the samples were tested by $\mathrm{X}^{2}$ and $\mathrm{t}$ di Student analysis through Statistica software (ver. 7).

\section{Results}

Table 1 reports the values of palmar dermatoglyphic patterns for Corsicans and Sardinians of both sexes and the statistical results of the comparison. Comparison between Corsican and Sardinia populations is also illustrated in Figures 2-4. There are no significant differences in the qualitative traits between Sardinians and Corsicans in both sexes. When we compare Corsicans with other Mediterranean populations, some interesting points emerge: with a value of 0.73 for the radial modal type/ulnar modal type ratio, the Corsicans join other populations with values lower than 1 , such as the Sardinians (0.88), Italians (0.94), Spaniards (0.95), Moroccans (0.77) and Tunisians (0.81), but not the French (1.15) (Floris, 2014). For the quantitative traits, there are significant differences for the a-b ridge count in both sexes (higher values in Sardinian males and lower ones in

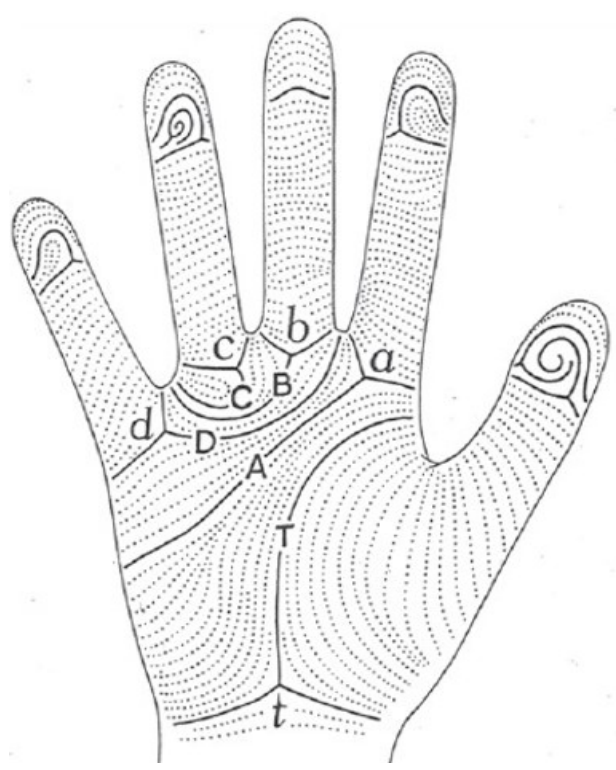

Figure 1. Main lines and triradii of the palm. 
Table 1. Comparison corsicans vs Sardinians.

\begin{tabular}{|c|c|c|c|c|c|c|}
\hline & \multicolumn{2}{|c|}{ Sardinians } & \multicolumn{4}{|c|}{ Corsicans } \\
\hline & Males (421) & Females (399) & \multicolumn{2}{|c|}{ Males (54) } & \multicolumn{2}{|c|}{ Females (53) } \\
\hline Hypothenar area & 34.08 & 37.59 & \multicolumn{2}{|c|}{25.00} & \multicolumn{2}{|c|}{39.05} \\
\hline $\begin{array}{c}\text { Thenar/first int. } \\
\text { area }\end{array}$ & 13.06 & 12.15 & \multicolumn{2}{|c|}{15.24} & \multicolumn{2}{|c|}{10.68} \\
\hline II interdigital area & 4.99 & 1.75 & \multicolumn{2}{|c|}{4.63} & \multicolumn{2}{|c|}{1.89} \\
\hline III interd, area & 45.13 & 37.12 & 40 & & \multicolumn{2}{|c|}{41.90} \\
\hline IV interd. area & 64.84 & 69.67 & 64 & & \multicolumn{2}{|c|}{63.46} \\
\hline $\mathrm{X}^{2}$ & Malesx Males & Femalesx Females & & & & \\
\hline Hypothenar area & 3.25 & 0.07 & & & & \\
\hline $\begin{array}{c}\text { Thenar/first int. } \\
\text { area }\end{array}$ & 0.34 & 0.17 & & & & \\
\hline II interdigital area & 0.02 & 0.25 & & & & \\
\hline III interd. area & 0.85 & 0.61 & & & & \\
\hline IV interd. area & 3.57 & 1.47 & & & & \\
\hline & & Modal types of C line & & & & \\
\hline & Males (1000) & & Male & (50) & $\mathrm{X}$ & \\
\hline ulnar & 41.70 & & 45 & & & \\
\hline radial & 36.85 & & 33 & & & \\
\hline Proximal + absent & 21.45 & & 22 & & & \\
\hline & & & & & 0. & \\
\hline radial/ulnar & 0.88 & & 0. & & & \\
\hline & & $\mathrm{a}-\mathrm{b}$ ridge count & & & & \\
\hline & Males (418) sd & Females (391) sd & Males & 53) sd & Females & (52) sd \\
\hline & $83.03 \quad 10.20$ & $81.07 \quad 9.48$ & 80.09 & 8.41 & 85.62 & 12.45 \\
\hline $\mathrm{t}$ & Malesx Males 2.06* & Femalesx Females $3.26^{\star \star}$ & & & & \\
\hline & & A-d ridge count & & & & \\
\hline & Males (418) sd & Females (391) sd & Males & 50) sd & Female & (38)sd \\
\hline & 22.89 & 20.60 & 92.36 & 20.57 & 93.53 & 22.36 \\
\hline $\mathrm{t}$ & Malesx Males 2.07* & Femalesx Females 0.78 & & & & \\
\hline & & Main line index & & & & \\
\hline & Males (418) sd & Females (391) sd & Males & 50) sd & Female & (40)sd \\
\hline & 16.05 & 15.50 & 15.98 & 3.54 & 16.30 & 3.90 \\
\hline $\mathrm{t}$ & Malesx Males 0.13 & Femalesx Females 1.33 & & & & \\
\hline
\end{tabular}

Sardinian females) and for the A-d ridge count in males alone (higher values in Sardinian males), but not for the main line index. 


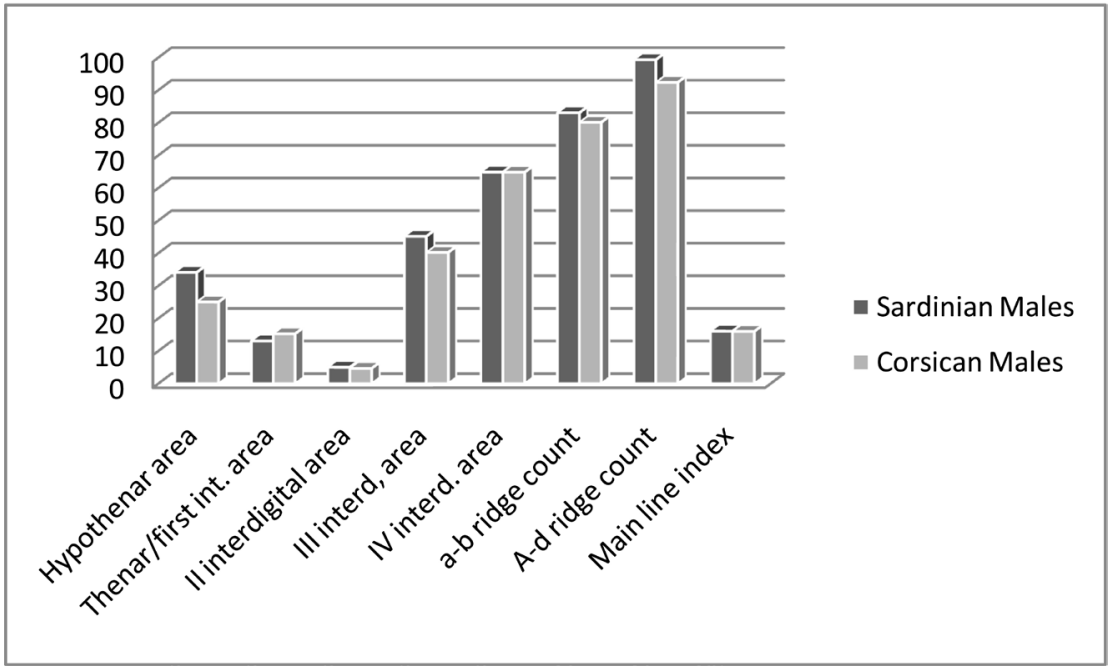

Figure 2. Patterns and vestiges in the 5 palmar areas in Corsican and Sardinian male populations.

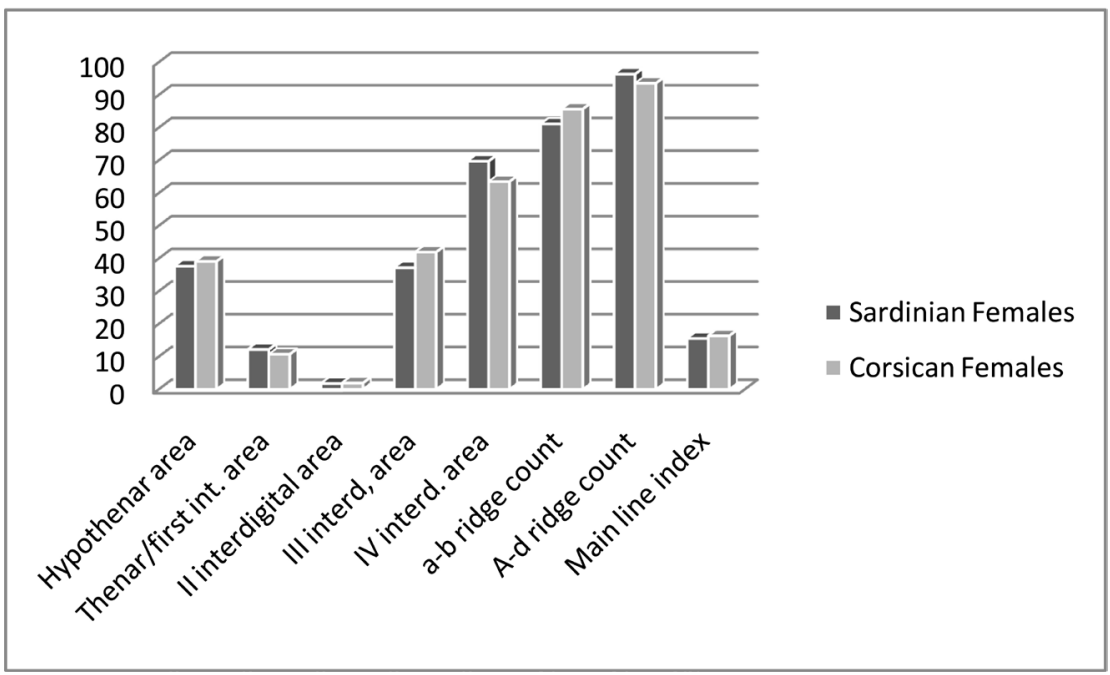

Figure 3. Patterns and vestiges in the 5 palmar areas in Corsican and Sardinian female populations.

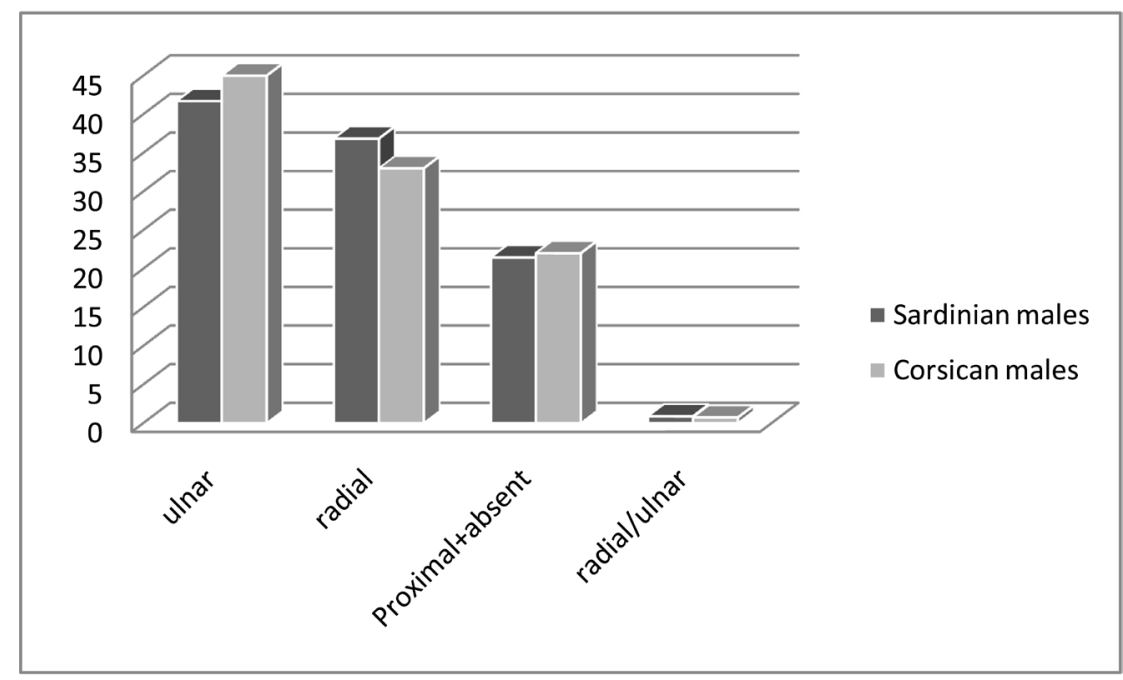

Figure 4. Modal types of C line in Corsican and Sardinian populations. 


\section{Conclusion}

The study of some dermatoglyphic traits shows that the Corsican and Sardinian populations are similar but not identical, with several significant differences (such as the a-b ridge count).

As demonstrated also by research on various genetic markers, the similarity is likely due to the origin and the history of the islands. In fact, Corsican and Sardinian populations derive from a common genetic founding pool, being subjected over the centuries to similar evolutionary forces (Vona et al., 2002; Piras et al., 2005; Giovannoni et al., 2006).

The similarities between the two islands were previously evidenced by researches on classical and molecular markers. A comparison of the four phenotypes of the ABO system reported for Sardinians (Floris and Maxia, 1979) with those Khérumian and Moullec, 1959; Vallois and Marquer, 1964) shows the same high frequency of O $(56.19 \%$ in the Corsicans and $53.87 \%$ in the Sardinians) but a $\mathrm{X}^{2}$ of 7.54 which for d.f. $=3$ is at the limit of significance (7.81) mainly because of a greater decrease of group B in the Corsicans $(6.49 \%$ vs $8.90 \%)$. These results agree with those of previous studies on classical autosomal markers and uniparental mtDNA and Y chromosome markers (Piras et al., 2005; Francalacci et al., 2003; Vona et al., 2002) which showed a strong genetic link between Sardinia and Corsica, probably due to the frequent mutual exchanges between the two islands since the Paleolithic.

It is worth noting that the genetic affinity between Corsica and Sardinia is more evident when the central part of the Corsica is analyzed, since its geographical isolation allowed it to maintain the ancient genetic characteristic (Vona et al., 2002).

On the other hand, in this work, we demonstrated that no perfect identity between the two islands.

The observed differences between them can be explained mainly by random genetic drift with subsequent isolation and endogamy. The effect of genetic drift was surely amplified by the low population density and the bottleneck effects caused by epidemics (such as malaria and plague) and strong isolation of the two islands, as shown by the rates of endogamy and consanguinity or surnames analysis (Sanna et al., 2004; Francalacci and Morelli, 1999).

\section{Conflicts of Interest}

The authors declare no conflicts of interest regarding the publication of this paper.

\section{References}

Adetona, M. O., Oladapo, O. O., \& Igbigbi, P. S. (2008). Palmar and Digital Dermatoglyphic Patterns of the Three Major Ethnic Groups in Nigeria. African Journal of Medical Sciences, 37, 333-337.

Floris, G. (1975a). Qualitative Aspects of Palmar Dermatoglyphics in a Sample of Sardi- 
nian Population. Journal of Human Evolution, 4, 573-577.

Floris, G. (1975b). Sex and Side Differences and Correlations Between Quantitative Palmar Characteristics in a Sample Sardinian Population. American Journal of Physical Anthropology, 42, 277-280.

Floris, G. (1977). Presence of Correlations between the Five Palmar Area Patterns. American Journal of Physical Anthropology, 47, 415-418.

Floris, G. (1992). I dermatoglifi digito-palmari negli italiani. Nota I-Dermatoglifi digitali, Antropologia Contemporanea, 15, 43-48.

Floris, G. (2014). Polimorfismi della linea C nei Sardi. In C. Peretto, M. Arzarello, \& J. Arnaud (Eds.). Variabilità umana tra passato e presente, 10/2 (pp. 275-278), Università degli Studi di Ferrara.

Floris, G., \& Maxia, C. (1979). Caratteristiche genotipiche dei Sardi e loro relazioni con quelle di altre popolazioni europee. Antropologia Contemporanea, 2, 9-13.

Francalacci, P., \& Morelli, L. (1999). Risultati preliminari dell'analisi dei cognomi di 13 comuni corsi. Antropologia Contemporanea, Monografia: La Corsica aspetti Antropologici, 45-64.

Francalacci, P., Morelli, L., Underhill, P. A., Lillie, A. S., Passarino, G., Useli, A., Madedda, R., Paoli, G., Tofanelli, S., Calò, C. M., Ghiani, M. E., Varesi, L., Memmi, M., Vona, G., Liu, A. A., Oefner, P., \& Cavalli-Sforza, L. L. (2003). Peopling of Three Mediterranean Islands (Corsica, Sardegna and Sicily) Inferred by Y Chromosome Biallelic Variability. American Journal of Physical Anthropology, 121, 270-279.

Giovannoni, L., Falchi, A., Piras, I. S., Amoros, J. P., Moral, P., Ghiani, M. E., Calò, C. M., Paoli, G., Varesi, L., \& Vona, G. (2006). Structure gégétique de la population Corse. Antropo, 11, 37-50.

Jantz, R. L., \& Chopra, V. P. (1983). A Comparison of Dermatoglyphic Methodologies in Population Studies. American Journal of Physical Anthropology, 60, 61-67.

Khérumian, R., \& Moullec, J. (1959). Note Préliminaire sur les groupes sanguins des Corses. Transfusion, 1, 245-248.

Mbaka, G., Ejiwunmi, A., Alabi, O., \& Olatayo, T. (2016). Digital Dermatoglyphic Variation and Migratory Pattern of Ethnic Liberians. Egyptian Journal of Forensic Sciences, 4, 416-421.

Morelli, L., Vona, G., Varesi, L., Memmi, M., Autuori, L., \& Calò, M. C. (1999). Finger Dermatoglyphics in the Corsican Population (France). Anthropologischer Anzeiger, 57, 339-347.

Piquet-Thepot, M. M. (1963). Contribution à l'étude du phénomène anthropologique en Corse. Paris: Thèse Faculté des Sciences.

Piras, I., Vona, G., Falchi, A., Latini, V., Ristaldi, S., Vacca, L., Varesi, L., \& Calò, C. M. (2005). $\beta$-Globin Cluster Haplotypes in Normal Individuals and $\beta 39$-Thalasemia Carriers from Sardinia, Italy. American Journal of Human Biology, 17, 765-772.

https://doi.org/10.1002/ajhb.20442

Plato, C. C. (1970). Polymorphism of the C Line of Palmar Dermatoglyphics with a New Classification of the C Line Terminations. American Journal of Physical Anthropology, 33, 413-420. https://doi.org/10.1002/ajpa.1330330315

Sanna, E., Iovine, M. C., \& Floris, G. (2004). Evolution and Marital Structure in 20 Sardinian Villages from 1800 to 1974. Anthropologischer Anzeiger, 62, 169-184.

Temaj, G., Milicic, J., Skaric, J. T., Behluli, I., Smolej, N. N., Hadziselimovic, R. et al. (2009). Comparative Analysis of Dermatoglyphic Traits in Albanian and Turkish Population Living in Kosovo. Collegium Antropologicum, 33, 1001-1005. 
Vallois, H. V., \& Marquer, P. (1964). La repartition en France des groupes sanguins ABO. Bulletins et Mémoires de la Société d'Anthropologie de Paris, 6, 1-200.

https://doi.org/10.3406/bmsap.1964.1245

Varesi, L., Memmi, M., Moral, P., Mameli, G. E., Succa, V., \& Vona, G. (1996). La distribution de quatorze marqueurs genétique dans la population de l'île de Corse (France). Bulletins et Mémoires de la Société d'Anthropologie de Paris, 8, 5-14. https://doi.org/10.3406/bmsap.1996.2424

Vona, G., Memmi, M., Calò, C. M., Latini, V., Succa, V., Ghiani, M. E., Moral, P., \& Varesi, L. (2002). Genetic Structure of the Corsican Population (France): A Review. Recent Res. Devel. Human Genet., Research Signpost, 1, 147-164. 